\title{
Collaborated development of the Beijing-Tianjin-Hebei region to improve regional environmental quality
}

\author{
X. Li \& Y. Wei \\ Beijing Energy Conservation and Environmental Protection Center, \\ PR China
}

\begin{abstract}
The Beijing-Tianjin-Hebei region is a comparatively large city group in China, with an area of around $217,000 \mathrm{~km}^{2}$, and a population of about 100 million people. Due to the different administrative divisions, regional collaboration has many obstacles to overcome - the development plan and policies cannot be connected, industrial layout needs to be further improved, population distribution is imbalanced, traffic development meets bottlenecks, infrastructure fails to match up with demand, resources and energy efficiencies need to be raised, especially air quality deterioration - forcing the coordinated development of the BeijingTianjin-Hebei region. The central government pushed forward the coordinated development of Beijing-Tianjin-Hebei as a national strategy in 2014. This article carried out the investigation and study on the economy, population, the industrial distribution, road traffic, ecological and atmospheric environment of BeijingTianjin-Hebei region, found existing problems in the process of development, then proposed suggestions for the coordinated development planning for the BeijingTianjin-Hebei region, focusing on improving environmental quality for the entire region, which could be used as a reference for government decision-making. Keywords: regional collaborated development, functional orientation, planning assumption, environment improvement.
\end{abstract}

\section{Introduction}

Located in the northeast of China, the Beijing-Tianjin-Hebei region consists of the Beijing Municipality, Tianjin Municipality and Hebei Province. As one of the biggest city groups in China, it has an area of $217,000 \mathrm{~km}^{2}$, representing around 
$2.2 \%$ of the country's total, and has a population of around 100 million, representing more than $7 \%$ of the country's total. In 2014, the region recorded a GDP of 1.07 trillion dollars, accounting for $10.5 \%$ of the country's total. This region is China's political and cultural center, as well as a major economic area in north China.

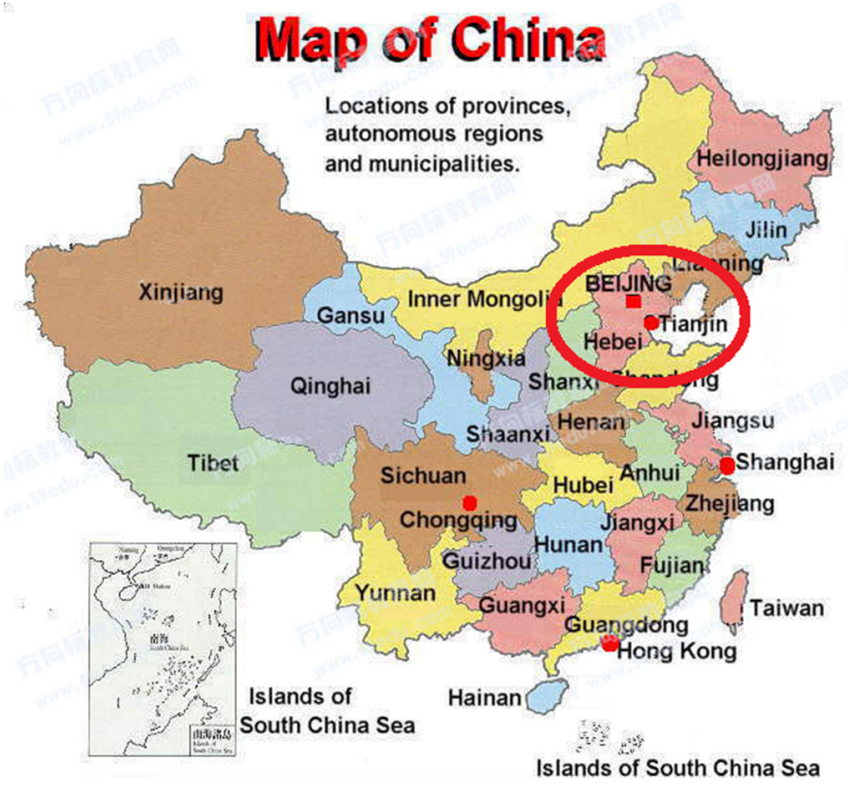

Figure 1: Geographical location of the Beijing, Tianjin and Hebei region.

At the work meeting held by the State Council on February $26^{\text {th }}, 2014$, Secretary General Xi Jinping, for the first time, clearly noted that it is a significant national strategy to achieve the coordinated development in the Beijing-TianjinHebei region, and it's essential to open new approaches for scientific and sustainable coordination development. On March $5^{\text {th }}$, 2015, Premier Li Keqiang made it clear in his government work report, "We will step up coordinated development for the Beijing-Tianjin-Hebei region and ensure that the region makes substantive breakthroughs in areas such as integrated transportation, environmental protection, and industry upgrading and relocation.”

\section{Comparison of the social, economic and environmental situation between Beijing, Tianjin and Hebei}

Beijing, Tianjin and Hebei intersect with one another geographically and interdependent economically, but independent of one another administratively. Due to the difference in resources and conditions, these three areas have highly unbalanced development level, and differ greatly in social, economic and environmental aspects. 
It can be seen from Table 1 that the Hebei Province has an area 11.8 times that of Beijing and 15.8 times that of Tianjin. In terms of population density, Beijing and Tianjin are basically equal, while Hebei Province's population is only a bit more than 1/4 of that of Beijing. The per-capita vehicle ownership of Beijing is double that of Hebei Province. The highway mileage per area unit in Beijing and Tianjin are 1.4 times that in Hebei Province respectively.

Table 1: Foundation Status of Beijing [1], Tianjin [2] and Hebei [3] in 2014.

\begin{tabular}{|l|l|l|l|}
\hline Item & Beijing & Tianjin & Hebei \\
\hline Area $\left(10,000 \mathrm{~km}^{2}\right)$ & 1.6 & 1.2 & 18.9 \\
\hline Percent of mountainous area $(\%)$ & 61.4 & 5.8 & 48.1 \\
\hline Permanent population $(10,000$ people) & 2151.6 & 1516.8 & 7383.8 \\
\hline Population density (person/ $\left./ \mathrm{km}^{2}\right)$ & 1311.0 & 1269.3 & 391.1 \\
\hline Vehicle ownership $(10,000$ units) & 559.1 & 280.0 & 997.0 \\
\hline Per-capita vehicle ownership (unit/person) & 0.25 & 0.18 & 0.13 \\
\hline Total highway mileage $(10,000 \mathrm{~km})$ & 2.2 & 1.6 & 17.9 \\
\hline Highway per unit area $\left(\mathrm{km} / \mathrm{km}^{2}\right)$ & 1.3 & 1.3 & 0.9 \\
\hline
\end{tabular}

As shown in Table 2, the per-capita GPD of Beijing and Tianjin are basically equal, while that of Hebei accounts for only around $40 \%$ of Beijing or Tianjin. Arranged in the order of descending importance, Beijing is featured with the structure of tertiary-secondary-primary industry, while Hebei has a structure of secondary-tertiary-primary industry, with the primary industry making up a relatively large proportion.

Table 2: $\quad$ Economic development status of Beijing [1], Tianjin [2] and Hebei [3] in 2014.

\begin{tabular}{|l|l|l|l|l|}
\hline Item & $\begin{array}{l}\text { GDP } \\
(100 \text { million US\$) }\end{array}$ & $\begin{array}{l}\text { Increase } \\
(\%)\end{array}$ & $\begin{array}{l}\text { Per-capital GDP } \\
\text { (US\$/person) }\end{array}$ & $\begin{array}{l}\text { Primary, secondary, } \\
\text { tertiary industry ratio }\end{array}$ \\
\hline Beijing & 3472.4 & 7.3 & 16278 & $0.7: 21.4: 77.9$ \\
\hline Tianjin & 2559.4 & 10.0 & 16874 & $1.3: 49.4: 49.3$ \\
\hline Hebei & 4789.4 & 6.5 & 6641 & $11.7: 51.1: 37.2$ \\
\hline
\end{tabular}

Data from Table 3 show that Hebei Province's total energy consumption is considerably higher than that of Beijing and Tianjin, i.e., 4.3 times that of Beijing and 3.4 times that of Tianjin. Its energy consumption per 10,000 yuan GDP is also notably higher than Beijing and Tianjin, i.e., 3.1 times that of Beijing and 1.8 times that of Tianjin. Meanwhile, the energy consumption structures of Beijing and Tianjin are obviously better than Hebei, with Beijing's clean energy other than coal accounting for $76.3 \%$, Tianjin's clean energy $56 \%$, and Hebei's clean energy $11.4 \%$. 
338 Sustainable Development, Vol. 1

Table 3: Energy consumption status of Beijing, Tianjin and Hebei in 2014 [4].

\begin{tabular}{|c|c|c|c|c|c|c|}
\hline \multirow{2}{*}{ Item } & \multicolumn{2}{|c|}{ Beijing } & \multicolumn{2}{|c|}{ Tianjin } & \multicolumn{2}{|c|}{ Hebei } \\
\hline & Value & $\begin{array}{c}\text { Increase } \\
(\%)\end{array}$ & Value & $\begin{array}{c}\text { Increase } \\
(\%)\end{array}$ & Value & $\begin{array}{c}\text { Increase } \\
(\%)\end{array}$ \\
\hline $\begin{array}{l}\text { Total energy } \\
\text { consumption }\end{array}$ & 7455 & 1.4 & 9440 & 7 & 32119 & 3 \\
\hline $\begin{array}{l}\text { Energy } \\
\text { consumption }\end{array}$ & 0.35 & -5.5 & 0.60 & -5 & 1.1 & -3.2 \\
\hline $\begin{array}{l}\text { Energy } \\
\text { consumption } \\
\text { structure }\end{array}$ & \multicolumn{2}{|c|}{ Beijing } & \multicolumn{2}{|c|}{ Tianjin } & \multicolumn{2}{|c|}{ Hebei } \\
\hline Coal (\%) & \multicolumn{2}{|c|}{23.7} & \multicolumn{2}{|c|}{44.0} & \multicolumn{2}{|c|}{88.6} \\
\hline Power (\%) & \multicolumn{2}{|c|}{24.6} & \multicolumn{2}{|c|}{11.5} & \multicolumn{2}{|c|}{1.8} \\
\hline $\begin{array}{l}\text { Natural gas } \\
(\%)\end{array}$ & \multicolumn{2}{|c|}{17.9} & \multicolumn{2}{|c|}{5.6} & \multicolumn{2}{|c|}{2.2} \\
\hline $\begin{array}{l}\text { Refined oil } \\
(\%)\end{array}$ & \multicolumn{2}{|c|}{31.7} & \multicolumn{2}{|c|}{12.2} & \multicolumn{2}{|c|}{7.4} \\
\hline
\end{tabular}

It can be seen from Table 4 that the air quality in Beijing, Tianjin and Hebei is relatively poor. However, compared with Beijing, the air quality in Tianjin and Hebei is even worse. Beijing is more capable of pollution control than Tianjin and Hebei.

Table 4: Environmental status of Beijing [5], Tianjin [6] and Hebei [7].

\begin{tabular}{|l|c|c|c|}
\hline Item & $\begin{array}{c}\text { Beijing } \\
(2014)\end{array}$ & $\begin{array}{c}\text { Tianjin } \\
(2013)\end{array}$ & $\begin{array}{c}\text { Hebei } \\
(2013)\end{array}$ \\
\hline $\mathrm{PM}_{10}$ annual average $\left(\mu \mathrm{g} / \mathrm{m}^{3}\right)$ & 116.0 & 150 & 190 \\
\hline $\mathrm{NO}_{2}$ annual average $\left(\mu \mathrm{g} / \mathrm{m}^{3}\right)$ & 56.7 & 54 & 51 \\
\hline $\mathrm{SO}_{2}$ annual average $\left(\mu \mathrm{g} / \mathrm{m}^{3}\right)$ & 21.8 & 59 & 74 \\
\hline $\begin{array}{l}\text { Harmless treatment rate of domestic garbage } \\
(\%)\end{array}$ & 99.6 & 95 & 92 \\
\hline Central urban area sewage treatment rate $(\%)$ & 97.0 & 95 & 93.6 \\
\hline City-wide sewage treatment rate $(\%)$ & 90.0 & 87.5 & - \\
\hline
\end{tabular}




\section{Bottlenecks in the three areas' development}

\subsection{Unbalanced development of urban system, excessive development of metropolis, inadequate development of sub-central cities, and dispersed development of county towns}

Excessive concentration of resources has resulted in serious deterioration of the "big city malaise" in Beijing. The concentration of communication facilities, networks and terminals in Beijing has turned Beijing into a place where too many vehicles pass through. The Capital Airport accounts for $85 \%$ of the regional air passengers and $86 \%$ of the freight volume. Currently, the railway and expressway network in the Beijing-Tianjin-Hebei region forms a single-core radiation structure with Beijing as the center. Meanwhile, the total floor area in Beijing's central urban area has exceeded 600 million square meters. The excessive concentration of city functions and rapid motorization have led to severe traffic jam problems.

The development of sub-central cities lags behind. In the Beijing-TianjinHebei region, except for Beijing and Tianjin, all other cities with districts have a population of no more than 3 million. Cities with a population of more than 500,000 lag far behind comparable cities in the Yangtze River Delta and the Pearl River Delta, in terms of comprehensive strength, economic openness, integrated transport hub functions, urban commercial service functions, and regional innovation capabilities.

County towns undergo scattered and disorderly development. The economic development of county towns in the Beijing-Tianjin-Hebei region is relatively slow. The GDP and total retail sales of consumer goods of the more than 140 counties (cities) in this area account for only $1 / 3$ of the region's total, and the added value of their tertiary industry accounts for only $1 / 4$ of the region's total. A considerable percent of the population engages in agricultural work in Hebei, which leads to heavy employment pressure.

\subsection{Fragile ecosystem, scarce water resources, inefficient land use, severe environmental pollution}

Water resources have become a most critical ecological problem in the BeijingTianjin-Hebei region. The per-capita water resource amount in the region is less than $300 \mathrm{~m}^{3} /$ year, representing only $1 / 7$ of the country's average. Due to the drying up of rivers, the water system's capacity for regulating the ecosystem has weakened significantly, causing frequent occurrence of desertification phenomenon, urban heat island effect, and rain island effect. Meanwhile, with the gradual expansion of the urban land for construction, and due to the shortage of ecological and municipal infrastructure, megacities are facing the problem of serious waterlogging, and affected by the strange phenomenon that regional water shortage and flooding damage in urban area exist at the same time. 
Land is inefficiently used, and the ecosystem for green belt forests has degenerated. During 2003-2014 in Beijing, the land used for urban construction grew by $444.5 \mathrm{~km}^{2}$, while, the rural collective land used for construction increased to $1,804 \mathrm{~km}^{2}$ from $840 \mathrm{~km}^{2}$. Rural land for construction replaces a large amount of arable and forest land. The ecosystem of the forests within $120 \mathrm{~km}$ surrounding Beijing has severely degraded.

The Beijing-Tianjin-Hebei region has become one of the area most affected by the environmental pollution problem. According to the $\mathrm{PM}_{2.5}$ monitoring data released by the country's 945 monitoring stations during the year from April 2013 to April 2014, the air pollution in the Beijing-Tianjin-Hebei region exceeded the acceptable level more frequently than all other regions of the country, with Handan and Xingtai being the areas with most concentrated pollution. Meanwhile, it is also one of the regions with most serious water environmental pollution, rural surface source pollution and megacity environmental pollution.

\subsection{Defective road traffic system, unavailability of overall planning, and outstanding problems of broken end roads or bottleneck roads}

Under China's management system, railway, airport, highway and water transport facilities are managed by different departments respectively, and infrastructure construction is led by their competent administrative authorities, which has resulted in the coordinated management being ineffective and decentralized. The communications networks in the Beijing-Tianjin-Hebei region have failed to be managed in a well-coordinated manner.

The pressure on investment and fragmented administrative boundaries has made the planning of rail transport difficult to be coordinated and even more difficult to integrate their construction and operation. There are "broken-end roads" with a total length of $2,300 \mathrm{~km}$ among the expressways, state-level roads, and province-level roads connecting Hebei and Beijing/Tianjin. In fact, Beijing is current a transport hub for Hebei, even for the northern area of China, with a huge number of passengers moving in the areas by Beijing's various railway stations, bus stations and airports each day. This has not only increased pressure on Beijing's traffic, but also worsened its air pollution.

\subsection{Unreasonable industrial structure, serious same-structure phenomenon, and unformed regional integrated market}

Generally speaking, Beijing's tertiary industry occupies a dominant position and has entered the post-industrial era. Tianjin possesses such advantageous pillar industries as aerospace, electronic information and petrochemicals, and the second industry has long played a major in Tianjin's domestic gross product. Its tertiary industry grows slowly. As Hebei Province is in the middle stage of industrialization, the second industry featured with high consumption and pollution remains the leading sector, while tertiary industry has a low share and lacks growth momentum. 
According to the study of Hou and Wang [8], the benchmark 0.85 is applied in evaluating the degree of similarity of inter-regional industrial structures. It is learned from calculation that the factor of similarity of the industrial structure between Beijing and Tianjin is 0.8554, between Beijing and Hebei is 0.7583, however between Tianjin and Hebei comes to 0.9752, indicating a serious convergence of industrial structures between these two areas.

The regional integrated market has not taken shape. The market has failed to sufficiently play its leading role in the regional integrated development, and an industrial development structure featured with free flow of factors and efficient allocation of resources has not been established. The existing major problem lies in that priority is given to government rather than to the market, and that industrial cooperation lacks vitality.

\section{Major functional planning in Beijing, Tianjin and Hebei}

Beijing, Tianjin and Hebei, each makes its plan according to its own current local conditions and advantages, which has led to the unevenness in the development in the region. The conflict and unevenness in the three regions have been formed on a long-term basis, and are closely related to the major functional orientation of the overall planning, as shown in Tables 5, 6 and 7.

Table 5: Beijing's major functional division planning.

\begin{tabular}{|l|c|c|l|}
\hline $\begin{array}{l}\text { Major } \\
\text { functional zone }\end{array}$ & Area $\left(\mathrm{km}^{2}\right)$ & Proportion (\%) & Functional positioning \\
\hline $\begin{array}{l}\text { Capital function } \\
\text { core zone }\end{array}$ & 92.4 & 0.6 & $\begin{array}{l}\text { Optimize the development and } \\
\text { moderately limit the functions that do } \\
\text { not match the core area }\end{array}$ \\
\hline $\begin{array}{l}\text { Urban function } \\
\text { expansion zone }\end{array}$ & 1275.9 & 7.8 & $\begin{array}{l}\text { Focus on development and high-end } \\
\text { industries and develop international } \\
\text { urban-rural integration }\end{array}$ \\
\hline $\begin{array}{l}\text { Urban } \\
\text { development } \\
\text { new zone }\end{array}$ & 3782.9 & 23.0 & $\begin{array}{l}\text { Focus on development and accelerate } \\
\text { the construction, of the new city and } \\
\text { optimize the economic zone }\end{array}$ \\
\hline $\begin{array}{l}\text { Ecological } \\
\text { development } \\
\text { zone }\end{array}$ & 11259.3 & 68.6 & $\begin{array}{l}\text { Focus on tourism, leisure and cultural } \\
\text { creativity, and promote the construction } \\
\text { of the new city, small towns and the } \\
\text { new countryside. }\end{array}$ \\
\hline
\end{tabular}


Table 6: Tianjin's major functional division planning.

\begin{tabular}{|l|c|c|c|}
\hline $\begin{array}{l}\text { Major functional } \\
\text { zone }\end{array}$ & $\begin{array}{c}\text { Area } \\
\left(\mathrm{km}^{2}\right)\end{array}$ & $\begin{array}{c}\text { Proportion } \\
(\%)\end{array}$ & \multicolumn{1}{c|}{ Functional positioning } \\
\hline $\begin{array}{l}\text { Optimized } \\
\text { development } \\
\text { zone }\end{array}$ & 6444.0 & 54.1 & $\begin{array}{c}\text { An important carrier of the urban } \\
\text { population, the demonstration area of } \\
\text { urban-rural integration and rapid } \\
\text { improvement of economic strength. }\end{array}$ \\
\hline $\begin{array}{l}\text { Major development } \\
\text { zone }\end{array}$ & 2454.1 & 20.6 & $\begin{array}{l}\text { An important growth pole for the city's } \\
\text { economic development and an important } \\
\text { cluster for the service industry and } \\
\text { education, R\&D conversion base. }\end{array}$ \\
\hline $\begin{array}{l}\text { Ecological } \\
\text { economy } \\
\text { development zone }\end{array}$ & 3021.6 & 25.3 & $\begin{array}{c}\text { An important area for guaranteeing } \\
\text { ecological security and supply of } \\
\text { agricultural products, important scenic } \\
\text { and tourist spot. }\end{array}$ \\
\hline $\begin{array}{l}\text { Development } \\
\text { prohibited zone }\end{array}$ & 1491.7 & 12.5 & $\begin{array}{c}\text { An important area for protecting the } \\
\text { natural cultural resources and the place for } \\
\text { guaranteeing ecological security }\end{array}$ \\
\hline
\end{tabular}

Notes: The prohibited development zone is dotted distributed in other areas.

Table 7: Hebei's major functional division planning.

\begin{tabular}{|c|c|c|c|}
\hline $\begin{array}{l}\text { Major functional } \\
\text { zone }\end{array}$ & $\begin{array}{l}\text { Area } \\
\left(\mathrm{km}^{2}\right)\end{array}$ & $\begin{array}{l}\text { Proportion } \\
\quad(\%)\end{array}$ & Functional orientation \\
\hline $\begin{array}{l}\text { Optimized } \\
\text { development zone }\end{array}$ & 26994 & 14.38 & $\begin{array}{l}\text { The national important base of new } \\
\text { industrialization, an important traffic } \\
\text { hub and channel for going to sea, and an } \\
\text { important undertaking place for the } \\
\text { industry transfer of Beijing and Tianjin }\end{array}$ \\
\hline $\begin{array}{l}\text { Major } \\
\text { development zone }\end{array}$ & 29313 & 15.62 & $\begin{array}{l}\text { Major construction area of } \\
\text { industrialization and urbanization }\end{array}$ \\
\hline $\begin{array}{l}\text { Development- } \\
\text { limited zone }\end{array}$ & 40600 & 21.63 & $\begin{array}{l}\text { Major construction area for agricultural } \\
\text { production, demonstration zone of new } \\
\text { countryside }\end{array}$ \\
\hline $\begin{array}{l}\text { Development- } \\
\text { prohibited zone }\end{array}$ & 18488 & 9.85 & $\begin{array}{l}\text { An important area for protecting the } \\
\text { cultural and nature resources. An } \\
\text { important area for protecting the } \\
\text { production capacity of food supplies. }\end{array}$ \\
\hline
\end{tabular}

Notes: about $38.5 \%$ of the land belongs to the unplanned mountainous area.

It can be seen that the major functions of the three regions are quite different. Beijing's four functional zones are focusing on internationalized and high-end industries, fostering the cultural creative industries and establishing the ecological 
development zone. Tianjin's development focuses on improving the economic strengthen of the city, energetically developing the modern manufacturing industry and scientific and technological R\&D bases. Hebei's development focuses on new industrialized base undertaking the industry transfer and urbanization construction of Beijing and Tianjin.

The development planning of the three regions is independent from each other, lacking the top-level design of the coordinated development. Therefore, it is not conducive to the overall layout of the industries and protecting the ecological environment.

\section{Several suggestions for improving the quality of regional environment through coordinated development in the Beijing-Tianjin-Hebei region}

(1) The Beijing, Tianjin and Hebei urban system planning should be conducted under the precondition of the bearing capacity of the resource environment, transformation of functions, coordinated planning, and establishing the negotiation and coordination mechanism.

Under the new development background, the urban system planning of Beijing-Tianjin-Hebei should be conducted under the precondition of the bearing capacity of the resources environment, properly handle the relationship between urban construction, economic development and ecological environmental protection, rationally allocate resources. The model of spatial development should transform from the closed inland cluster model to sea-land linkage, opening up both internally and externally, and multi-center coordinated development.

As for the cross-regional ecological environmental protection, the governments of the three regions should focus on coordination and jointly develop the regional pollution treatment and regional ecological recovery, and put forward planning strategies on the protection and rational development and utilization of water resources, intensive utilization of rural land resource, energy security guarantee, and the protection and rational utilization of inshore resources.

It is necessary to establish the Beijing-Tianjin-Hebei urban-rural planning consultation system, especially the planning implementation mechanism, and incorporate the overall development goal, coordination focus and coordinated countermeasures into the relevant legal planning of the three regions.

(2) Unify the industry access standard, utilize each own advantages and characteristics to establish an industry layout with complementary advantages

The Beijing-Tianjin-Hebei region should establish a unified regional industry access and environment policy system and take "treating air pollution and improving the ecological environment" as an important goal of industry structure optimization. In the process of eliminating backward production capacity and filling in new industries, it is necessary to avoid the situation of "transfer of pollution" and energetically develop the low-carbon environmental protection industry. 
Beijing should establish a sophisticated economic structure, pay attention to the development of the knowledge-based service sectors of the tertiary industry, strengthen service function and radiation capacity, boost the comprehensive driving capacity as the core city in the Beijing-Tianjin-Hebei region, thus making itself the political, cultural, foreign communication and scientific and technological innovation center. Tianjin should accelerate the pace of developing the modern metro-type agriculture and energetically develop the modern service industry while maintaining powerful second industry strength. Meanwhile, it should also speed up the pace of building the land-air 3-dimensional linkage system and rapid logistics concentration network, gradually undertake the functions as the economic center, international shipping center, and modern manufacturing base in north China. For Hebei, firstly, energetically develop the ecological and suburban modern agriculture in around Beijing and Tianjin region and strive to establish itself as Beijing's ecological zone and the supply base for non-staple food products such as vegetable. Secondly, further optimize the internal structure of the second industry, strengthen industrial technical transformation, eliminate surplus production capacity, and develop the low-carbon industry. Thirdly, give priority to developing the production-oriented service industry and life-oriented service industry, give full play to the tourist resources of Qinhuangdao, Chengde, and Zhangjiakou, building itself into the leisure and oldage base serving Beijing and Tianjin.

(3) Perfect the regional environment legal system, improve the environment monitoring network, strengthen joint defense and control, and establish the ecological compensation mechanism.

The legal system is the key to restricting the environmental pollution in the Beijing-Tianjin-Hebei region. Three areas should unified the environment policies and laws. The law-making of environment should be conducted under the precondition of "sustainable development" and under the principle of "focus on precaution, give priority to protection, attach equal importance to ecological construction and treat pollution."

To perfect the regional environment monitoring network. It is necessary to establish an all-inclusive, 3-dimensional, and round-the-clock environment pollution and ecological environment monitoring system featuring rational layout, advanced equipment, complete functions in order to improve the real-time monitoring over environment pollution and conduct medium- and long-term monitoring over ecological evolution and disasters, as well as the ability of giving warnings and conducting emergency over sudden pollution disasters.

It is necessary to perfect the ecological compensation mechanism. A part of the regional ecological compensation fund should be used for supporting the regional ecological construction projects, and a part of it should be directly used by the enterprises that have closed or cut production and their employees due to the construction of ecological environment, as well as the families that need to move for the sake of environmental protection. 
(4) Break the regional barrier in traffic construction, unified planning and simultaneously construction, optimize the spatial layout of industry development. To realize the industry collaboration smoothly, priority should be given to traffic. It is necessary to promote the effective linkage of the traffic infrastructural facilities in the three regions in planning, construction and technical standards, effectively solving the problem with "broken ends", and establish an integrated traffic system. It is advisable to define the five major ports in Hebei and Tianjin featuring rational layout, specific labor division, complementary advantages and resource conservation. In order to realize traffic integration, the three regions must design from the top level and break the system and mechanism barriers under the coordination of the Central government and the relevant ministries and commissions.

\section{Conclusions}

To improve the environment quality, the three regions must follow the road of coordinated development. The integration in the three regions must be conducted under the precondition of reasonable utilization of resources. The three regions must establish perfect policy and legal systems, unified standards and rational ecological compensation mechanism, and ensure the implementation of the planning and design contents through an effective consultation and coordinated mechanism.

Some advices of this study have been taken in the "Collaborative Development Planning of Beijing-Tianjin-Hebei region", which has been approved by the State Council. Also this study provides important reference for the local government of Beijing, Tianjin and Hebei in the decision-making in sustainable development policies.

\section{References}

[1] Beijing municipal bureau of statistics, 2014 Beijing Municipal Economy and Social Development Bulletin, pp. 1-5.

[2] Tianjin municipal bureau of statistics, 2014 Tianjin Municipal Economy and Social Development Bulletin, pp. 2-8.

[3] Hebei Province bureau of statistics, 2014 Hebei Municipal Economy and Social Development Bulletin, pp. 2-6.

[4] National Bureau of Statistics, 2014 China Energy Statistical Yearbook, pp. 34.

[5] Beijing municipal bureau of environmental protection, 2014 Beijing Municipal Environment Bulletin, 3 pp.

[6] Tianjin municipal bureau of environmental protection, 2014 Tianjin Municipal Environment Bulletin, 2 pp.

[7] Hebei municipal bureau of environmental protection, 2014 Hebei Municipal Environment Bulletin, 3 pp.

[8] Hou, X. F., Wang D., Comparative study on industrial structure of Beijing, Tianjin and Hebei, Industry Observation, 28, $34 \mathrm{pp}$. 